\title{
Language Courses as Potential Indicators of Translation Performance: An Exploratory Study
}

\author{
Oudah Alenazi ${ }^{1}$ \\ ${ }^{1}$ College of Languages and Translation, King Saud University, Riyadh, Saudi Arabia \\ Correspondence: Oudah Alenazi, PO BOX 87907, College of Languages and Translation, King Saud University, \\ Riyadh 11652, Saudi Arabia. E-mail: oalenazi@ksu.edu.sa
}

Received: October 20, 2018 Accepted: November 13, 2018 Online Published: February 24, 2019

doi:10.5539/ijel.v9n2p145 URL: https://doi.org/10.5539/ijel.v9n2p145

\begin{abstract}
Linguistic competence is a key factor in the preparation of translation students. Although translation competence encompasses linguistic competence, the interaction between the two calls for empirical exploration. This study examines whether students' performance, particularly in language skills, can be a potential indicator of the quality of their translations. A total of forty-eight translation students from a college of languages and translation in the Kingdom of Saudi Arabia were recruited to participate in the study. Students marks in previous language skills courses were statistically correlated with their marks in the final exam of a translation course. The results indicated a significant positive association between two language skills, namely grammar and reading, and students' competence in translation. The writing skill, however, showed no significant impact on students' performance in translation. This study has practical implications for students in translation programmes, teachers of language skills courses in these programmes, and those in charge of curriculum.
\end{abstract}

Keywords: translation competence, linguistic competence, language skills, student translators

\section{Introduction}

Translation is the process of transferring a text from one language to another. A translator's competence in translation is often referred to as 'transfer competence'. Translation has a crucial role to play in an increasingly globalised and multilingual world where people use it daily (Leonardi, 2010). As Duff (1994) puts it, translation happens everywhere and all the time. Preparation of student translators involves, inter alia, the acquisition of linguistic skills. This is often done through the inclusion of courses like reading, writing, vocabulary, grammar, listening, and speaking in translation programmes.

Although translators are expected to have an excellent command of basic language components such as grammar, vocabulary, and pronunciation in order to produce high quality translations, these components are often taken for granted in translation studies. In the college where I teach, many teachers and I have noticed that there are discrepancies in students' quality of translation and have attributed that to the students' competence in the English language. For example, many students struggle to produce simple, grammatically correct English sentences. Others have difficulties with punctuation marks and capitalisation, and some do not know the meanings of common English words and phrases.

Since translation and language learning are closely linked, it is assumed that there exists a relationship between the performance of translation students in these language skills courses and their overall performance in written translations.

This study, therefore, endeavours to quantitatively explore the links and potential relationships between the performance of translation students in three language skills courses with their performance in translation final exams. The paper starts with a review of the relevant literature, provides details of the research methodologies utilised, presents and discusses the results, and finally, indicates its limitations as well as its practical and pedagogical implications.

\section{Literature Review}

In English as a Foreign Language (EFL) settings, students' linguistic competence seems of crucial importance to their translation competence. According to PACTE (2000, p. 2), even the term 'translation competence' is borrowed from the idea of linguistic competence. It refers to the underlying system of knowledge and skills 
needed for students to be able to translate.

Many translation theorists (Fawcett, 1987; Meersseman, 2004; Gouadec, 2007) rightly maintain that the education of translators should equip them with a set of "transferable skills that will place them in a position to deal confidently with any text, on any subject, within any situation at any time" (Tennent, 2005, p. 24). Indeed, if translators are to succeed, "they need to master a relatively independent user stage in their language learning" (Popescu, 2013, pp. 1075-1076).

Similarly, Horbacauskiene, Kasperaviciene, and Petroniene (2017) believe that translators' preparation programmes should focus on five competences: translation competence, linguistic and textual competence, research competence, cultural competence, and technical competence. Of high relevance to this paper are the first two-translating competence, which is defined by Horbacauskiene et al. (2017, p. 148) as "the ability to translate texts and to assess the problems of text comprehension and production" and linguistic and textual competence, which they define as "the ability to understand the source language and having an excellent knowledge of the target language in the context of a wide range of texts, including specialised genres."

Translation competence is believed to consist of various subcomponents that include linguistic aspects. PACTE (2000, p. 4) summarises these subcomponents as: (1) communicative competence in two languages, including linguistic, discourse and sociolinguistic competence; (2) extra-linguistic competence, composed of general world knowledge and specialist knowledge; (3) instrumental-professional competence, composed of knowledge and skills related to the tools of the trade and the profession; (4) psycho-physiological competence, defined as "the ability to use all kinds of psychomotor, cognitive and attitudinal resources" including "psychomotor skills for reading and writing; cognitive skills (e.g., memory, attention span, creativity and logical reasoning); psychological attitudes (e.g., intellectual curiosity, perseverance, rigour, a critical spirit, and self-confidence)"; (5) transfer competence, which is "the ability to complete the transfer process from the ST (source text) to the TT (target text), i.e., to understand the ST and re-express it in the TL (target language), taking into account the translation's function and the characteristics of the receptor"; and (6) strategic competence, which includes "all the individual procedures, conscious and unconscious, verbal and non-verbal, used to solve the problems found during the translation process."

Given this close relatedness between linguistic and translating competences, it is only logical to assume that the higher the linguistic competence of EFL students, the better their translation quality is expected to be. As Neubert (1995, p. 412) emphasises, "There would be no grounds for transfer competence (translation) without the translator's thorough grounding in language competence and subject competence." However, there seems to exist insufficient literature on the interaction between students' performance in translation and specific language courses, notably reading, grammar, vocabulary and writing.

Farahani and Siyyari (2015), for example, argue for the reading-based notion of translation. That is, translation is viewed as a kind of reading, and unless a translator grasps the content of the ST through reading skills, he or she will find it virtually impossible to translate and produce the TT. Similarly, Munday $(2001$, p. 8$)$ asserts that translation exercises are "regarded as a kind of learning a new language or of reading a foreign language text until one had the linguistic ability to read the original." Newmark (1991) stresses that in order for translators to understand a text, both general and close reading are required. In this sense, general reading helps translators to get the gist of a text while close reading helps with challenging texts in terms of word meanings and contexts. Leonardi (2009) asserts that reading is linked to translation in that it takes a careful reading of a text before it can be translated. Dagiliene (2012, p. 125) also emphasises that translation "might provide a guided practice in reading", arguing that careful text analysis improves the reading comprehension of students and helps to develop their vocabulary. Prior to the commencement of translating any text, a careful reading and a detailed analysis are needed "in order to determine the contents in terms of what, how and why it is said" (Leonardi, 2009, p. 143).

In the same vein, Nation (1997) addresses the relevance of vocabulary learning to translation, highlighting that translation is beneficial for vocabulary acquisition because bilingual word lists may well facilitate for learners the acquisition of new words and phrases, particularly in the early stages of learning vocabulary. According to Petrocchi (2006), translation is a useful tool in developing language systems such as grammar, syntax and vocabulary in both the target language and the source language.

Similarly, translation is seen as a resource for helping students to improve their skills in writing courses. That is, translation is a process of transferring a particular text from one language to another. The produced text, therefore, should "flow naturally, re-create both the style and the context of the original text, and follow target language conventions" (Dagiliene, 2012, p. 125).

Moreover, one well-known approach to language teaching involves translation. The grammar-translation method 
is "the explicit study of grammar rules, followed by the completion of grammar exercises and the translation of sentences illustrating particular grammar points, to and from the foreign language" (Cook \& Singleton, 2014, p. $111)$.

This 19th century method was predominantly used in Europe to teach classical languages such as Latin and Ancient Greek. Later, modern languages started to be taught using the grammar-translation method. Fotos (2005, p. 655) asserts that grammar was viewed "as the way to read classical texts [...] Word by word, heavily supported by interlinear and/or marginal glosses [...] and parallel translation [...], students read edifying passages and single sentences from classical literature." Benelhadj Djelloul and Neddar (2017, p. 163) opine that the grammar-translation method "gave much importance to grammar rules that have been taught through translation into the learners' own language at the expense of communication skills and fluency." Opponents of this method such as Carreres (2006) and Malmkjaer (2010), however, argue that translation was a counter-productive tool in EFL learning as it promotes to the learners the notion that there is a one-to-one relationship between the source language and the target language. According to Benelhadj Djelloul and Neddar (2017), debates on the use of translation in language classes saw objections that are based on the failure of the grammar-translation method.

Following this review of the literature, it is obvious that these existing studies discuss the relationship between linguistic competence and translation competence without closely examining the interaction between the two competences. This is an obvious gap in the literature. Specifically, the interplay between specific language courses and student performance in translation remains unexplored. In other words, although the relationship between foreign language courses and translation competence is obvious, this study seeks to examine how certain courses affect this relationship. This study aims to fill this gap by exploring whether there is an interaction between students' linguistic performance in three language courses (reading, writing and grammar) and the overall performance in a translation course.

\section{Methodology}

\subsection{Participants}

The study recruited 48 male student participants. All of them were BA students at the College of Languages and Translation at King Saud University in Riyadh, Saudi Arabia. All of them were of the same age group (21-22 years old). The students were all enrolled in a translation course that is taught by the researcher after having successfully passed all language skills components, i.e., reading, writing, grammar, vocabulary, listening and speaking.

\subsection{Procedure}

Participants were administered a placement test using the Oxford Placement Test (OPT) one week before the final exam. The aim was to account for potential discrepancies in students' marks in the courses investigated since they were taught the same course books by different teachers.

Participating students were asked to voluntarily disclose their marks in three courses: Reading 3, Grammar 3, and Essay and Summary Writing (Advanced Writing). These are the last courses that students must take before they can register for translation courses. These courses were selected because of their significance to translation courses since translation mainly involves the reading of a text, the writing of a corresponding text or translation, and using grammatical knowledge in the production of their translation (see Appendix A for details of the three courses). Volunteering participants were also told that their final exam marks would be used in the study. All of them signed a consent form for their voluntary participation. One week before the final exam, they were asked to take a placement test. This was to minimise the chances for any additional learning or language improvement that might take place before the final exam. In addition, the translation course requires students to translate from and into English. Their marks in the three courses and their marks in the placement test were statistically correlated with their marks in the final exam of a written translation course using a statistical software. It is worth mentioning that only the students' final marks were used in the study; that is, marks for students' participation and course work were excluded to render more reliable results.

\subsection{Research Questions}

The study seeks to answer the following two main questions:

1) Do any of the three courses (Reading 3, Grammar 3, Essay and Summary Writing) have an impact on Saudi EFL students' marks in the translation final exam? 
2) Is there a significant relationship between Saudi EFL students' performance in the placement test and their marks in the translation final exam?

\section{Results}

The students' marks in the final exam of the translation course were examined against their marks in three previous courses. Specifically, the students' marks were correlated using Pearson Correlations with their marks in Grammar 3, Reading 3, and Essay and Summary Writing. Table 1 below lists all the correlations found.

Table 1. Correlations of students' marks

\begin{tabular}{|c|c|c|c|c|c|c|c|}
\hline & & Reading 3 & Grammar 3 & Writing 3 & Skills Average & Placement Test & Final Exam \\
\hline Reading 3 & $\begin{array}{l}\text { Pearson Correlation } \\
\text { Sig. (2-tailed) }\end{array}$ & 1 & & & & & \\
\hline Grammar 3 & $\begin{array}{l}\text { Pearson Correlation } \\
\text { Sig. (2-tailed) }\end{array}$ & $\begin{array}{l}0.502^{* *} \\
0.000\end{array}$ & 1 & & & & \\
\hline Writing 3 & $\begin{array}{l}\text { Pearson Correlation } \\
\text { Sig. (2-tailed) }\end{array}$ & $\begin{array}{l}0.491^{* *} \\
0.000\end{array}$ & $\begin{array}{l}0.367^{*} \\
0.010\end{array}$ & 1 & & & \\
\hline Skills Average & $\begin{array}{l}\text { Pearson Correlation } \\
\text { Sig. (2-tailed) }\end{array}$ & $\begin{array}{l}0.813^{* *} \\
0.000\end{array}$ & $\begin{array}{l}0.780^{* *} \\
0.000\end{array}$ & $\begin{array}{l}0.797^{* *} \\
0.000\end{array}$ & 1 & & \\
\hline Placement Test & $\begin{array}{l}\text { Pearson Correlation } \\
\text { Sig. (2-tailed) }\end{array}$ & $\begin{array}{l}0.140 \\
0.394\end{array}$ & $\begin{array}{l}0.158 \\
0.336\end{array}$ & $\begin{array}{l}0.084 \\
0.611\end{array}$ & $\begin{array}{l}0.158 \\
0.336\end{array}$ & 1 & \\
\hline Final Exam & $\begin{array}{l}\text { Pearson Correlation } \\
\text { Sig. (2-tailed) }\end{array}$ & $\begin{array}{l}0.317^{*} \\
0.028\end{array}$ & $\begin{array}{l}0.449^{* *} \\
0.001\end{array}$ & $\begin{array}{l}0.265 \\
0.069\end{array}$ & $\begin{array}{l}0.430^{* *} \\
0.002\end{array}$ & $\begin{array}{l}0.384^{*} \\
0.016\end{array}$ & 1.00 \\
\hline
\end{tabular}

Note. ${ }^{* *}$ Correlation is significant at the 0.01 level (2-tailed).

* Correlation is significant at the 0.05 level (2-tailed).

Placement Test and Translation Quality. As indicated earlier, the students' linguistic abilities were determined using the OPT. The analysis revealed a positive correlation between the students' performance in the placement test and their performance in the translation final exam. Although this positive correlation falls on the borderline between weak and moderate, it remains, nonetheless, significant. That is, the correlation coefficient for this association was 0.384 , and the $p$ value was 0.016 .

Reading and Translation Quality. The analysis revealed a moderate positive correlation between the students' marks in Reading 3 and their translation final exam marks. That is, there was a significant association between the students' reading competence and their performance in translation since the correlation coefficient was 0.317 and the $p$ value was 0.028 . Among the significant correlations presented in Table 1 above, the reading skill fell at the bottom of the list, as it came after Grammar 3, Placement Test, and Skills Average.

Writing and Translation Quality. The results showed no statistical significance in the association between the students' marks in the advanced writing course Essay and Summary Writing and their performance in the final exam of the written translation course. In other words, the correlation coefficient was 0.265 , and the $p$ value was 0.069 , indicating a weak, yet positive, correlation.

Grammar 3 and Translation Quality. The analysis of the results showed a statistically significant correlation between the students' marks in Grammar 3 and their final exam marks in translation. As can be seen in Table 1 above, the correlation coefficient for this relationship was 0.449 , and the $p$ value was 0.001 , indicating a moderate positive correlation. This correlation is the most significant association found in this study.

Skills Average and Translation Quality. It was statistically possible to obtain the average of students' marks in all three skills under examination: Reading 3, Essay and Summary Writing, and Grammar 3. The aim of combining these three courses was to eliminate the possibility of a student failing to do his best in a particular course for any reason, which will lead to a mark that does not adequately reflect his linguistic competence level. Rather, the average of the three skills of reading, grammar, and writing may well be a better indicator of competence. This average of skills showed a moderate positive correlation with students' marks in the final exam. As can be seen in Table 1, this association was the second highest significant correlation with a coefficient of 0.430 and a $p$ value of 0.002 , coming second to Grammar 3 .

\section{Discussion}

The results presented above show that the significant correlations revealed in the data analysis can be ordered 
according to their statistical significance. The most significant correlation was found between students' marks in Grammar 3 and their marks in the final exam of the written translation course. The second most significant correlation was revealed to be between the students' average marks in Reading 3, Grammar 3, and Essay and Summary Writing and their marks in the final exam of translation. After that came the association between their scores on the OPT and their performance in translation. The final significant association was found between the students' marks in Reading 3 and their marks in the final exam of the written translation course. There was no statistical significance found between students' marks in Essay and Summary Writing and their marks in the final exam of translation.

Before discussing these correlations in detail, it is worth noting that all of them were positive correlations. In other words, the more competent the students were in grammar, for example, the better their marks in translation were. Though logical, these positive associations show the importance of such language skills in any translation programme.

Interestingly, examining the most significant relationship-Grammar 3 and Translation-shows that understanding the grammatical structures of the target language can be an immensely beneficial tool in the preparation of student translators. That is, the higher the students' marks in grammar, the better their translations. Since students are required to translate from and into English, their translations are definitely affected by their mastery of grammar.

The next significant relationship was found between the average of students' marks in the three language skills and their marks in translation. This average was used to examine the students' linguistic competence in general terms. In other words, there can be students whose marks in a particular course, due to exceptional circumstances, might not individually reflect the students' competence as can the average of these marks. Indeed, the average of the three skills is a better indicator of the students' linguistic competence. This relationship between the students' translation competence and their marks in the three skills courses was found to be significant. This confirms a major finding of the current study; linguistic competence facilitates translation competence. This generally conforms to the findings of previous research, which established that linguistic competence constitutes a vital part of translation competence (Fawcett, 1987; Meersseman, 2004; Gouadec, 2007; Horbacauskiene et al., 2017).

In the same vein, the placement test was found to show a significant correlation with students' performance in translation. The test was used to measure the students' current linguistic competence rather than merely relying on their marks in the three courses from previous semesters. This result proves the previously discussed finding that linguistic competence influences translation competence.

The last significant correlation was found to be between Reading 3 and students' marks in the final exam of the written translation course. This significance is indeed logical. In many ways, reading is the cornerstone for translation; it is the means for understanding a text - the more clearly you understand a text, the more likely you will produce an adequate translation of it. This finding affirms the already-established relationship between reading and translation (Munday, 2001; Farahani \& Siyyari, 2015). This conforms to the notion that understanding a text requires both general and close reading (Newmark, 1991). Indeed, "if the translator has a good ability to read and comprehend the source text, s/he will be capable of adequately translating, even though his/her other abilities may not be at a high level" (Farahani \& Siyyari, 2015).

However, the results showed no statistical significance in the correlation between Essay and Summary Writing and students' marks in translation. Interestingly, one would have assumed that students' marks in this advanced writing course would indicate their potential in translation. This was not the case. Though statistically insignificant, the association was still a positive one, indicating - in a way-that the more competent in writing the students were, the better their marks in translation would be. Writing is, after all, a means of delivering the target text but, more importantly, a means of understanding the source text-just like reading. This, in turn, contributes immensely to ensuring an improved translation.

Overall, these findings clearly indicate the significance of the linguistic competence component of translation competence. This was clearly shown by the positive relationships found between Reading 3 and Grammar 3 on the one hand and students' marks in the written translation course on the other hand. Not only do these skills constitute a major part of any translation programme, but they also contribute directly to the quality of students' translations. This finding is in line with what Popescu (2013, p. 1075-1076) puts forward as a tool for the success of translators: "they need to master a relatively independent-user stage in their language learning."

Regarding the first research question, which asked, "Do any of the three courses (Reading 3, Grammar 3, Essay and Summary Writing) have an impact on Saudi EFL students' marks in the translation final exam?" the answer is yes indeed. As discussed earlier, Grammar 3 and Reading 3 both had a significant positive correlation with 
students' performance in translation; the more competent the Saudi EFL students were in these two advanced courses, the higher their marks in the final exam of translation were.

The second research question of this study asked, "Is there a significant relationship between Saudi EFL students' performance in the placement test and their marks in the translation final exam?" The answer is yes. The placement test had a significant positive correlation with students' performance in translation. The placement test can be an indicator of students' linguistic competence, which is a key factor in translation competence as discussed earlier (PACTE, 2000; Horbacauskiene et al., 2017).

\section{Limitations of the Study and Recommendations for Future Research}

The findings of this study are limited to the Saudi translation students at the College of Languages and Translation; they cannot be generalised to a wider population at this stage. This is due to the relatively small size of the sample. Another limitation of the study is that it used only one course for each skill of the three. Although the courses used (whether Reading 3, Grammar 3, or Essay and Summary Writing) are the most important courses because they are the most advanced courses in the respective skills, the study did not use an average of all the courses studied by the participants for each skill, i.e., Reading 1 and 2, Grammar 1 and 2, and Writing 1 and 2. This could have yielded more rigorous results.

Given the exploratory nature of the current study, further research is needed in this important area of teaching translation to corroborate the findings of this research. Also, more research is needed to investigate the relationship between linguistic competence and translation competence from the perspective of those who teach translation. As major stakeholders, the teachers' perspective can provide significant contributions to any investigation of this relationship.

\section{Conclusion and Implications}

The current study endeavoured to explore the relationship between linguistic competence, represented by the students' marks in three advanced language courses, and their translation competence, represented by the students' marks in the final exam of translation. It found that the more competent the students were in grammar and reading skills, the better they performed in translation. Similarly, it found that more linguistic competence on the students' part means better performance in translation.

There are various implications for these findings. First, translation programmes need to ensure that their students receive proper linguistic preparation, at least in grammar and reading. This in no way suggests that other courses shouldn't be integrated in such programmes. On the contrary, a good translation programme is one that equips students with excellent skills in all language courses. Similarly, the teaching of language skills in such programmes should be geared towards preparing future translators. Raising students' awareness of such findings may well motivate them and push them towards improving their language skills if they want to become better translators and compete in the job market. In other words, knowing that these courses can have a direct impact on the quality of their translation and, indeed, their marks would encourage them to do more in these courses.

\section{Acknowledgements}

The author would like to thank the Deanship of Scientific Research, King Saud University, for funding this research project.

\section{References}

Benelhadj, D. D., \& Neddar, B. (2017). The Usefulness of Translation in Foreign Language Teaching: Teachers' Attitudes and Perceptions. Arab World English Journal for Translation \& Literary Studies, 1(3), 162-176. https://doi.org/10.24093/awejtls/vol1no3.11

Carreres, A. (2006). Strange bedfellows: Translation and language teaching. The teaching of translation into L2 in modern languages degrees; uses and limitations. Paper presented at the Sixth Symposium on Translation, Terminology and Interpretation in Cuba and Canada. December 2006. Canadian Translators, Terminologists and Interpreters Council. Retrieved July 9, 2018, from http://www.cttic.org/publications_06Symposium.asp

Cook, V., \& Singleton, D. (2014). Key topics in second language acquisition. Bristol: Multilingual Matters. https://doi.org/10.21832/9781783091812

Dagiliene, I. (2012). Translation as a Learning Method in English Language Teaching. Studies About Languages, 21, 124-129. https://doi.org/10.5755/j01.sal.0.21.1469

Duff, A. (1994). Translation: Resource Books for Teachers. Oxford: Oxford University Press.

Farahani, M., \& Siyyari, M. (2015). The Effect of Teaching Reading Comprehension Skills on Translation 
Quality of Iranian EFL learners. International Journal of Applied Linguistics \& English Literature, 4(1), $50-59$.

Fawcett, P. (1987). Putting translation theory to use. In K. Hugh \& I. Mas (Eds.), Translation in the Modern Languages Degree (pp. 31-38). London: CILT.

Fotos, S. (2005). Traditional and grammar translation methods for second language teaching. In E. Hinkel (Ed.), Handbook of Research in Second Language Teaching and Learning (vol. 1, pp. 652-670). London: Routledge

Gouadec, D. (2007). Translation as a profession. Amsterdam and Philadelphia: John Benjamins. https://doi.org/10.1075/btl.73

Horbacauskiene, J., Kasperaviciene, R., \& Petroniene, S. (2017). Translation studies: Translator training vs employers' expectations. Journal of Language and Cultural Education, 5(1), 145-159. https://doi.org/10.1515/jolace-2017-0009

Leonardi, V. (2009). Teaching Business English through Translation. Journal of Language \& Translation [online], 10(1), 139-153. https://doi.org/10.22425/jul.2009.10.1.139

Leonardi, V. (2010). The role of pedagogical translation in second language acquisition-from theory to practice. Berlin: Peter Lang. https://doi.org/10.3726/978-3-0351-0071-6

Malmkjaer, K. (2010). Language learning and translation. In G. Yves \& V. D. Luc (Eds.), Handbook of Translation Studies (vol. 1, pp. 185-190). Amsterdam: John Benjamins. https://doi.org/10.1075/hts.1.lan1

Meersseman, Y. (2004). The customer makes the difference. In LISA Best Practice Guide, Quality Assurance - the Client's Perspective (pp. 35-37). Fechy: Localisation Industry Standards Association.

Munday, J. (2001). Introducing translation studies. London: Routledge.

Nation, P. (1997). L1 and L2 Use in the Classroom: A Systematic Approach. TESL Reporter, 30(2), 19-27.

Neubert, A. (1995). Competence in language, in languages, and in translation. In C. Schaffner \& B. Adab (Eds.), Developing Translation Competence (pp. 3-18). Amsterdam: John Benjamins.

Newmark, P. (1991). About translation. Clevedon: Multilingual Matters.

PACTE. (2000). Acquiring translation competence: Hypotheses and methodological problems of a research project. In B. Allison, D. Ensinger \& P. Marisa (Eds.), Investigating translation (pp. 99-106). Amsterdam: John Benjamins. https://doi.org/10.1075/btl.32

Petrocchi, V. (2006). Translation as an Aid in Teaching English as a Second Language. Online Translation Journal [online], 10(4). Retrieved July 9, 2018, from http://www. translation directory.com/article1199.htm

Popescu, T. (2013). Developing English Linguistics Students' Translation Competence Through the Language Learning Process. Procedia - Social and Behavioral Sciences, 93, 1075-1079. https://doi.org/10.1016/j.sbspro.2013.09.333

Tennent, M. (2005). Training for the new millennium pedagogies for translation and interpreting. Amsterdam \& Philadelphia: John Benjamins. https://doi.org/10.1075/btl.6

\section{Appendix A}

\section{Information on the Three Courses}

Reading 3

- Aims: This course aims to help students understand texts for specific information; to identify discourse signals in inter and intra-paragraph positions, and manage reference within texts; and to summarize paragraph topics through close reading, and discriminate between major and minor statements within texts.

- Description: The course trains students to read and understand texts, focusing on: Developing their reading sub-skills of skimming and scanning for information, close reading, summarizing texts, inferring information, etc. Raising their awareness about the importance for meaning of the mechanics of language Reading and understanding texts are complemented by a language production activity.

- $\quad$ Credit hours: 3

Essay and Summary Writing 
- Aims: By the end of the course, students should achieve control of editing for correct form and function as well as editing for good organization and development. They also should plan a good thesis statement and build a repertoire of organizational patterns, introductions and conclusions. Finally, students should achieve control of control of brainstorming for essay writing.

- Description: The course marks a transition from the paragraph to the essay. It concentrates on the essential form and function of the essay, paving the ground for academic writing. Focus is on the thesis statement and its contribution to the cohesion and coherence of the whole essay. Particular importance is given to description and argumentation, which includes comparison, discussion of cause and effect, and speculation. Students are trained to summarize, paraphrase, quote, and generate thought. They are instructed to observe the major stages in the writing process, namely pre-writing, drafting, revising, and editing.

- $\quad$ Credit hours: 3

Grammar 3

- Aims: By the end of the course, students should know about the phonological, morphological, and syntactic differences between Arabic and English, know about the differences between the Arabic and English noun phrases, know about the syntactic and semantic differences between Arabic and English in terms of tense, aspect, mood, and modality, know about differences between Arabic and English in terms of some syntactic constructions, and know about the differences between Arabic and English conjunctions.

- Description: The course offers a contrastive study of English and Arabic at the phonological, morphological, and syntactic levels. The course also offers contrastive work on verbs, nouns, and conjunctions in both languages.

- $\quad$ Credit hours: 3

\section{Copyrights}

Copyright for this article is retained by the author, with first publication rights granted to the journal.

This is an open-access article distributed under the terms and conditions of the Creative Commons Attribution license (http://creativecommons.org/licenses/by/4.0/). 